\title{
ENHANCED BIOACCESSIBILITY BY EXTRUSION PROCESS AND QUALITY PARAMETERS OF RED PEPPER PULP ADDED EXTRUDATES
}

\author{
Ozge Yoldas $^{1}$, Cagla Caltinoglu-Toraman ${ }^{1}$, Ilkay Sensoy ${ }^{1 *}$, Sibel Karakaya ${ }^{2}$ \\ ${ }^{1}$ Department of Food Engineering, Middle East Technical University, Ankara, Turkey \\ ${ }^{2}$ Department of Food Engineering, Ege University, Izmir, Turkey
}

Received / Geliş: 11.10.2021; Accepted / Kabul: 22.12.2021; Published online / Online bask1: 30.12.2021

Yoldas, O., Caltinoglu-Toraman, C., Sensoy, I., Karakaya, S. (2022). Enhanced bioaccessibility by extrusion process and quality parameters of red pepper pulp added extrudates. GIDA (2022) 47 (1) 15-24 doi: 10.15237/gida.GD21131.

Yoldas, O., Caltinoglu-Toraman, C., Sensoy, I., Karakaya, S. (2022). Ekstrüzyon işlemiyle arttırılmış biyoerişim ve kırmızı biber posası eklenmiş ekstrüde ürünlerin kalite parametreleri. GID $A$ (2022) 47 (1) 15-24 doi: 10.15237/gida.GD21131.

\begin{abstract}
Only bioaccessible nutrients can be absorbed and used by the body to contribute to health. The study aimed to investigate the effect of extrusion on the in vitro bioaccessibility of $\beta$-cryptoxanthin and zeaxanthin in extrudates supplemented with red pepper pulp. Corn grits mixed with red pepper pulp were extruded. $\beta$-cryptoxanthin, zeaxanthin, and total phenolic content with antioxidant activity analysis were conducted on the feed and extruded samples. Quality parameters of the corn grit extrudates, prepared with and without red pepper pulp, were also investigated. The extrusion process significantly increased the in vitro bioaccesibiliy of zeaxanthin, but no statistically significant difference was observed for $\beta$-cryptoxanthin. After the extrusion process, total phenolic, $\beta$-cryptoxanthin, and zeaxanthin contents with antioxidant activity were lower. Physical quality parameters such as hardness, expansion, and water absorption with water solubility index values were not affected by the addition of red pepper meal. The porosity decreased, and hence the bulk density increased. Sensory analysis showed that the preference scores of the panelists for the samples with the addition of red pepper meal were not different from the control. This study showed that the extrusion process could improve the in vitro bioaccessibility of functional components. Additionally, red pepper pulp can be added as a functional ingredient to extrudates to develop new products without changing consumer preferences.
\end{abstract}

Keywords: Extrusion, bioaccessibility, quality, functional, digestion, sensory analysis

\section{EKSTRÜZYON ISŞLEMIYYLE ARTTIRILMIŞ BIYYOERİŞIM VE KIRMIZI BİBER POSASI EKLENMİŞ EKSTRÜDE ÜRÜNLERİN KALİTE PARAMETRELERİ}

\section{ÖZ}

Sadece biyolojik olarak erişilebilir besinler biyolojik olarak kullanılabilir ve vücut tarafindan sağlığa katkıda bulunmak için kullanılabilirler. Çalışma, ekstrüzyon işleminin kırmızı biber küspesi eklenmiş ekstrüdatlarda $\beta$-kriptoksantin ve zeaksantin'in in vitro biyoerişilebilirliği üzerine etkisini araştırmayı

\footnotetext{
${ }^{*}$ Corresponding author / Yazışmalardan sorumlu yazar

(1): isensoy@metu.edu.tr

Ozge Yoldas; ORCID no: 0000-0000-0000-0000

Cagla Caltinoglu-Toraman; ORCID no: 0000-0000-0000-0000

Illkay Sensoy; ORCID no: 0000-0002-0413-2532

Sibel Karakaya; ORCID no: 0000-0001-5514-9521 
amaçlamıştır. Ekstrüzyon işlemi, zeaksantin’in in vitro biyoerişilebilirliğini önemli ölçüde arttırmıştır, ancak $\beta$-kriptoksantin için istatistiksel olarak anlamlı bir fark izlenmemiştir. Ekstrüzyon işleminden sonra antioksidan aktiviteye sahip toplam fenolik, $\beta$-kriptoksantin ve zeaksantin içerikleri daha düşük bulunmuştur. Sertlik, genleşme, su emme ve suda çözünürlük indeks değerleri gibi fiziksel kalite parametreleri kırmızı biber küspesi ilavesinden etkilenmemiştir. Gözeneklilik azalmış ve dolayısıyla yığın yoğunluğu biraz artmıştır. Duyusal analiz, kırmızı biber küspesi ilave edilen numuneler için panelistlerin tercih puanlarının kontrolden farklı olmadığını göstermiştir. Bu çalışma, ekstrüzyon işleminin fonksiyonel bileşenlerin in vitro biyoerişilebilirliğini iyileştirebileceğini göstermiştir. Ek olarak, kırmızı biber küspesi, tüketici tercihlerini değiştirmeden yeni ürünler geliştirmek için ekstrüdatlara fonksiyonel bir bileşen olarak eklenebilir.

Anahtar kelimeler: Ekstrüzyon, biyoerişilebilirlik, kalite, fonksiyonel, sindirim, duyusal.

\section{INTRODUCTION}

Extrusion is a thermomechanical process that can produce various food products from cereals with varying textures and shapes with a high consumer appeal. Therefore, many scientists have studied the incorporation of nutrient-rich by-products of vegetables and fruits to improve the functionality of extruded food products (Dehghan-Shoar et al. 2011). Sweet red peppers (Capsicum annum $\mathrm{L}$.) are good candidates for extruded products as a functional ingredient due to their excellent contents of antioxidants, fiber, vitamins, and minerals. They contain vitamin C, nonprovitamin A carotenoid pigments including lycopene and zeaxanthin, and provitamin A carotenoids, $\beta$-carotene, and $\beta$-cryptoxanthin (Minguez-Mosquera et al. 1993). $\beta$-cryptoxanthin can quench singlet oxygen. Zeaxanthin has preventive effects against lipid peroxidation and protects cells from blue light damage (Krinsky et al. 2003). Moreover, zeaxanthin has protective effects against blindness among the elderly, agerelated macular degeneration, and age-related cataracts (Abdel-Aal et al. 2013; Mozaffarieh et al. 2003). In the form of pulp, red pepper can be easily incorporated into extruded snack products. Health claims for functional components can only be made if the ingredient reaches the target site for the required physiological action. Bioaccessibility is described as the amount of an ingested nutrient that is available for absorption in the digestive system, whereas; bioavailability is the fraction that is available in the bloodstream for utilization in the physiological functions or storage in the body (Van Buggenhout et al. 2010). Therefore, the availability of nutrients or antioxidants depends on their bioaccessibility as well as their concentration in the food (Carrilo et al. 2017). The processing method, the food matrix, and structure may affect the compound's release from food during digestion (Karakaya et al. 2016; Pineda-Vadillo et al. 2017) and their bioaccessibility. The compound's physicochemical properties, such as configuration, degree of linkage, and lipophilic character, also affect bioaccessibility. Bioaccessibility of nutrients could be determined by in vivo or in vitro methods. In vivo methods involve human or animal subjects; therefore, it provides direct data. In vitro models, on the other hand, is rapid, low-cost, and reproducible alternatives. Also, the procedure has no ethical constraint.

Carotenoids are synthesized and stored in plastids, which are a group of organelles found in plant cells. There are a limited number of studies on the effect of the extrusion process on functional components' bioaccessibility (Guven et al. 2018; Tonyali et al. 2020). Therefore, this study aimed to investigate the extrusion process' effect on the release of selected carotenoids from red pepper cells. In vitro bioaccessibilities of carotenoids, $\beta$-cryptoxanthin and zeaxanthin, found in red pepper pulp were investigated before and after processing. Added functional ingredients with high fiber content may reduce starch expansion during the extrusion process and reduce consumer appeal. Therefore, the effects of rep pepper pulp addition on the quality of extrudates and the effects of the extrusion process on functional components of red pepper pulp added products were also investigated. 


\section{MATERIALS AND METHODS \\ Materials}

Corn grits (Zea mays L.) received from Teknik Tarım (Manisa, Turkey) and red peppers (Capsicum annum L.) were obtained from a local grocery store (Ankara, Turkey). The chemical reagents used in the analyses were of analytical grade except for the ones used in HPLC analysis, where the reagents were HPLC grade (Yeğin, 2014).

\section{Extrusion process}

Stems and seeds of the washed red peppers were removed before cutting and blending (Cuisinart CBT700E, Stamford) for about 5 minutes, as described in Yeğin (2014). Corn grits (12.52 \pm $0.03 \%$ moisture) and red pepper pulp (92.29 \pm $0.05 \%$ moisture) were mixed in a mixer (Kitchen Aid, Ariston, USA) for 20 minutes to obtain a feed with $25 \pm 0.5 \%$ moisture content. Before the extrusion process, the feed, which had been kept in black plastic bags at $4^{\circ} \mathrm{C}$ overnight, was allowed to equilibrate at room temperature for 2 hours. A halogen moisture analyzer (MX-50, AND, Japan) at $160^{\circ} \mathrm{C}$ was used to determine moisture contents. A laboratory-scale co-rotating twinscrew extruder (Feza Machine Co. Ltd., Istanbul, Turkey) with a die diameter of $3 \mathrm{~mm}$ and a barrel length to diameter ratio of 25:1 was used for the extrusion process. Three different temperature profiles were used for barrel zones during the experiments: 1) $80^{\circ} \mathrm{C}, 90^{\circ} \mathrm{C}, 100^{\circ} \mathrm{C}$ and $130^{\circ} \mathrm{C}$ (die: $121^{\circ} \mathrm{C}$ ); 2) $80^{\circ} \mathrm{C}, 105^{\circ} \mathrm{C}, 130^{\circ} \mathrm{C}$ and $160^{\circ} \mathrm{C}$ (die: $142^{\circ} \mathrm{C}$ ) and 3$) 80^{\circ} \mathrm{C}, 90^{\circ} \mathrm{C}, 115^{\circ} \mathrm{C}$, and $145^{\circ} \mathrm{C}$ (die: $125^{\circ} \mathrm{C}$ ). The first two temperature profiles (screw speed of $225 \mathrm{rpm}$ ) were used for the in vitro digestion, total phenol, antioxidant and carotenoid analyses to compare the samples, extruded at two different temperature profiles, with the feed. The third temperature profile (screw speed of $175 \mathrm{rpm}$ ), where the expansion was maximum among the three temperature profiles, was used for investigating the effect of red pepper pulp addition on the quality of the corn grit extrudates. The feed flow rate was $36 \pm$ $1 \mathrm{~g} / \mathrm{min}$ for all three temperature profile sets. Samples were taken only when actual measured barrel zone temperatures and die temperatures varied $\pm 2^{\circ} \mathrm{C}$ from the set temperatures.

\section{Sample Preparations}

For in vitro digestion and functional component analysis, the extruded samples were ground with a blender (Waring 8011ES, USA) for 2 minutes and passed through a $425 \mu \mathrm{m}$ mesh sieve (Laboratory Test Sieve, Endecotts Ltd. England). Ground samples were kept at $-22^{\circ} \mathrm{C}$ in a freezer (Arçelik, Turkey) until the analysis. For quality parameter analysis, collected extruded samples were cut into $5 \mathrm{~cm}$ pieces and dried at $50 \pm 0.1^{\circ} \mathrm{C}$ for 5 hours in an oven (ES500, Nüve, Turkey). The dried samples' final moisture contents were $6.57 \pm 1.76 \%$ and $6.64 \pm 0.20 \%$ for the samples with and without red pepper pulp, respectively.

\section{In vitro digestion analysis}

In vitro digestion analysis was conducted at the Food and Nutrition Science Laboratory in the Food Engineering Department of Ege University, Izmir, Turkey (Yeğin, 2014). The method of Martos et al. (2010) was used with slight modifications to simulate human gastrointestinal digestion. Simulated salivary (SSF) and gastric (SGF) fluids were prepared according to KopfBolanz et al. (2012) with some modifications (Table 1). The main steps of digestion were given as follows: Oral digestion was simulated by grinding the samples in a porcelain mortar. Then, $0.5 \mathrm{~g}$ of the ground matrices were mixed with 1.0 $\mathrm{mL}$ of SSF containing $\alpha$-amylase $(150 \mathrm{U} / \mathrm{mL})$ for $2 \mathrm{~min}$ at $37^{\circ} \mathrm{C}$ followed by gastric digestion with the addition of SGF containing pepsin solution (1000 U/mL; Sigma-Aldrich P7012, Germany) for $2 \mathrm{~h}$ at $37^{\circ} \mathrm{C}$. After gastric digestion, the $\mathrm{pH}$ was increased to 5.5, and a dialysis bag (Spectra/Por Dialysis Membrane MWCO: 68000, Spectrum Laboratories, Inc.) including 6.25 $\mathrm{mL} 0.5 \mathrm{~N} \mathrm{NaHCO}_{3}(\mathrm{pH} 7.0$ ) was put into a tube, and the tube was allowed to stay for incubation. Then $2 \mathrm{~mL}$ of the solution containing bile extract $(10 \mathrm{mM})$ and pancreatin (Sigma-Aldrich P1750, Germany) solution (100 U/mL, based on trypsin activity) was added and allowed for incubation under stirring for two hours at $37^{\circ} \mathrm{C}$. After the incubation period, the dialysis membrane was removed from the tube, opened, and the content was transferred into a $15 \mathrm{~mL}$ plastic tube marked as dialysate. The solution (non-dialysable fraction) outside the dialysis membrane was transferred 
into another tube. Then all the tubes were frozen at $-20^{\circ} \mathrm{C}$ overnight. Frozen samples (dialysates and non-dialysable fractions) were transported to the Food Engineering Department of the Middle East Technical University in Ankara for analysis of $\beta$-cryptoxanthin and zeaxanthin contents.

Table 1. Preparation of the digestion juices (saliva and gastric juice) (Kopf-Bolanz et al. 2012).

\begin{tabular}{lccccc}
\hline & Saliva & & \multicolumn{3}{c}{ Gastric Juice } \\
\hline Volume $(\mathrm{mL})$ & Compound & Stock $(\mathrm{g} / \mathrm{L})$ & Volume $(\mathrm{mL})$ & Compound & Stock $(\mathrm{g} / \mathrm{L})$ \\
\hline 10 & $\mathrm{KCl}$ & 46.72 & 28 & $\mathrm{KCl}$ & 46.72 \\
1 & $\mathrm{KSCN}$ & 40 & 0.9 & $\mathrm{KH}_{2} \mathrm{PO}_{4}$ & 68 \\
20 & $\mathrm{KH}_{2} \mathrm{PO}_{4}$ & 68 & 6.5 & $\mathrm{NaHCO}_{3}$ & 168 \\
4 & $\mathrm{NaHCO}_{3}$ & 84 & 10 & $\mathrm{NaCl}$ & 120 \\
1 & $\mathrm{NaCl}$ & 120 & 2 & $\mathrm{MgCl}_{2}\left(\mathrm{H}_{2} \mathrm{O}\right)_{6}$ & 30 \\
1 & $\mathrm{MgCl}_{2}\left(\mathrm{H}_{2} \mathrm{O}\right)_{6}$ & 30 & 1 & $\mathrm{NH}_{4} \mathrm{Cl}$ & 27.28 \\
\hline
\end{tabular}

\section{Extraction of carotenoids}

Carotenoids were extracted as described in Cemeroglu (2010) with some modifications. Ten grams of homogenized samples of finely ground extrudates and feed were put in a glass beaker, and $30 \mathrm{~mL}$ of distilled water was added. The beakers were wrapped in paraffin and aluminum foil. After that, they were kept in a refrigerator at $4^{\circ} \mathrm{C}$ overnight for hydration. The equilibrated samples were homogenized by a homogenizer (Witeg, HG-15A, Germany) at $13500 \mathrm{rpm}$ for 2 minutes. Then, 4 grams of homogenized samples were weighed into a glass beaker, and $0.4 \mathrm{~g}$ calcium carbonate $\left(\mathrm{CaCO}_{3}\right)$ was added to neutralize any organic acids. The samples were mixed with 25 $\mathrm{mL}$ of hexane/acetone/ethanol (50:25:25 v/v/v) mixture. The mixture in beakers wrapped in paraffin and aluminum foil was stirred with a magnetic stirrer (JeioTech-Multichannel Stirrer, MS-52 M, Korea) at $250 \mathrm{rpm}$ for 20 minutes. After stirring, the supernatant was separated and put into a glass beaker. Extraction with the mixture was performed twice to make the sample colorless and to extract carotenoids completely. Then, the supernatant is combined with the previous supernatant in a centrifuge tube. Then, $10 \mathrm{~mL}$ distilled water was added to supernatants, and tubes were centrifuged (Sigma, 2-16 PK, Germany) at $9500 \mathrm{xg}$ at $4^{\circ} \mathrm{C}$ for 20 minutes to separate the hexane layer. The hexane layer on top was separated into glass tubes with a microsyringe and evaporated under the stream of nitrogen at $37^{\circ} \mathrm{C}$ with a nitrogen evaporator.

\section{HPLC Analysis}

$\beta$-cryptoxanthin and zeaxanthin contents were determined as described in O'Connell et al. (2007) with some modifications. Carotenoids of feed and extrudate samples in the glass tubes were reconstituted in $100 \mu \mathrm{L}$ of tetrahydrofuran (THF) to split from glass entirely and then dissolved in $900 \mu \mathrm{L}$ of mobile phase including acetonitrile/methanol/dichloromethane (75:20:5 $\mathrm{v} / \mathrm{v} / \mathrm{v})$ mixture containing $10 \mathrm{mmol} / \mathrm{L}$ of ammonium acetate, $4.5 \mathrm{mmol} / \mathrm{L}$ butylated hydroxytoluene, and $3.6 \mathrm{mmol} / \mathrm{L}$ triethylamine. The carotenoids of digested feed and extrudate samples were reconstituted in $50 \mu \mathrm{L}$ of THF and then dissolved with $450 \mu \mathrm{L}$ of the mobile phase. The mixtures in the tubes were mixed with a vortex and were filtered through the $0.45 \mu \mathrm{m}$ syringe filter (Syringe Filter, PTFE $13 \mathrm{~mm}$ ) into brown glass vials. The carotenoid contents were determined by a reverse-phase HPLC. The HPLC system (Thermo Scientific, Finnigan Surveyor) consisted of a UV visible detector (Finnigan Surveyor, UV-Vis Plus Detector). The column system consisted of a guard column connected to Inertsil ODS-2, 4.6 x $250 \mathrm{~mm}, 5 \mu \mathrm{m}$ reverse-phase $\mathrm{C} 18$ column. The column temperature was $20^{\circ} \mathrm{C}$, and the visible detector was set to $450 \mathrm{~nm}$. The injection volume was $25 \mu \mathrm{L}$, and the isocratic flow rate was $1 \mathrm{~mL} / \mathrm{min}$. The mobile phase was filtered through a $0.45 \mu \mathrm{m}$ filter (Filtration Membranes, Membrane Disc PVDF $47 \mathrm{~mm}, 0.45 \mu \mathrm{m})$. The standard curves of $\beta$-cryptoxanthin (SigmaAldrich C6368, $\geq 97 \%$ (TLC), Germany) and zeaxanthin (Sigma-Aldrich 14681, $\geq 97 \%$ (TLC), Germany) were prepared with a range of 
concentrations from $0.0025 \mu \mathrm{g} / \mathrm{mL}$ to 0.1 $\mu \mathrm{g} / \mathrm{mL}$. Bioaccessibility (\%) of $\beta$-cryptoxanthin and zeaxanthin in the samples were calculated as follows: Bioaccessibility $(\%)=[$ (amount in dialyzed portion) + (amount in not dialyzed portion)] x100 / (amount in the sample before in vitro digestion)

\section{Total phenolic content and antioxidant activity}

Extractions were performed by the method of Anton et al. (2009). $400 \mathrm{mg}$ of samples were mixed with $10 \mathrm{~mL}$ of acetone/water $(4: 1 \mathrm{v} / \mathrm{v})$ mixture in glass beakers wrapped by paraffin and aluminum foil. The mixtures were stirred (JeioTech-Multichannel Stirrer, MS-52 M, Korea) at $200 \mathrm{rpm}$ for 2 hours. After that, the samples were centrifuged (Sigma, 2-16 PK, Germany) at $3000 \times \mathrm{xg}$ and $20^{\circ} \mathrm{C}$ for 12 minutes. The supernatants were taken by a syringe and filtered through a $0.45 \mu \mathrm{m}$ sterile syringe filter (Syringe Filter, PTFE $25 \mathrm{~mm}$ ). Total phenolic contents of the samples were determined according to the method given by Anton et al. (2009) with some modifications. $0.8 \mathrm{~mL}$ extract of the samples was taken into a $25 \mathrm{~mL}$ glass beaker and mixed with 6 $\mathrm{mL}$ of Folin-Ciocalteau reagent (Merck, Germany) freshly diluted 10-fold. After 5 minutes, $6 \mathrm{~mL}$ of sodium carbonate solution including $\mathrm{Na}_{2} \mathrm{CO}_{3}$ and distilled water in proportion to $60 \mathrm{~g} / \mathrm{L}$ was added into the beaker. Glass beakers wrapped by paraffin and aluminum foil were allowed to incubate at room temperature in the dark for 90 minutes. Acetone-water (80:20 $\mathrm{v} / \mathrm{v})$ mixture was used as a blank. Absorbances were read at $725 \mathrm{~nm}$ by using a UV-Visible spectrophotometer (Shimadzu, UV-1700, Japan) at $21^{\circ} \mathrm{C}$. The calibration curve was prepared with gallic acid (3,4,5-trihydroxy benzoic acid, SigmaAldrich, Germany) in a linear range of 20-200 $\mathrm{mg} / \mathrm{L}\left(\mathrm{R}^{2}=0.998\right)$. The samples' antioxidant activities were measured, according to Anton et al. (2009), with slight modifications. $0.8 \mathrm{~mL}$ of the extract of the samples was put into a $25 \mathrm{~mL}$ glass beaker wrapped by paraffin and aluminum foil. $15.2 \mathrm{~mL}$ of a stable radical 2,2-diphenyl-1picrylhydrazyl DPPH (Sigma-Aldrich, Germany) solution (6.34 x $10^{-5} \mathrm{M}$ in methanol) was added and let stay for 30 minutes. Absorbances were measured with a UV-Visible spectrophotometer (Shimadzu, UV-1700, Japan) at $517 \mathrm{~nm}$ and $21^{\circ} \mathrm{C}$. The control sample was prepared with a $0.8 \mathrm{~mL}$ acetone/water $(4: 1 \mathrm{v} / \mathrm{v})$ mixture and $15.2 \mathrm{~mL}$ of DPPH solution. Methanol was used as a blank. The calibration curve prepared with Trolox (6hydroxy-2,5,7,8-tetramethylchroman-2-

carboxylic acid, Sigma-Aldrich, Germany) was in the range $10 \mu \mathrm{M}$ to $100 \mu \mathrm{M}\left(\mathrm{R}^{2}=0.99\right)$.

\section{Expansion characteristics}

Bulk densities of the extrudates were determined according to Caltinoglu et al. (2014). True density analysis was performed at Middle East Technical University Central Laboratory using a helium pycnometer (Quantachrome Ultrapycnometer 1000, Florida, USA). A digital caliper was used to determine extrudates' diameters. Sectional expansion index (SEI) and porosity values were calculated according to the following equations (Caltinoglu, 2014; Caltinoglu et al. 2014; Pai et al. 2009; Sahin and Sumnu 2006): SEI $=\left(D_{e} / D_{d}\right)^{2}$ where; $\mathrm{D}_{\mathrm{e}}$ is the diameter of the extrudate $(\mathrm{mm})$ and $\mathrm{D}_{\mathrm{d}}$ is the diameter of the die $(\mathrm{mm})$. Porosity $=1-\varrho_{\text {(extrudate) }} / \varrho_{\text {(true) }}$, where; $\varrho_{\text {(extrudate) }}$ is the bulk density of the extrudate $\left(\mathrm{g} / \mathrm{cm}^{3}\right)$ and $\varrho_{\text {(true })}$ is the true density of the extrudate $\left(\mathrm{g} / \mathrm{cm}^{3}\right)$.

\section{Texture}

A texture analyzer (TA.XTPlus, Stable Micro Analyzer, UK) in compression mode was used for the extrudates' hardness measurements as described in Caltinoglu (2014) and Caltinoglu et al. (2014).

\section{Water absorption index (WAI) and water solubility index (WSI)}

WAI and WSI were determined according to Caltinoglu et al. (2014) with the following equations: WAI $(\mathrm{g} / \mathrm{g})=\mathrm{m}_{\text {sediment }} / \mathrm{m}_{\text {dry }}$, WSI $(\%)$ $=\left(\mathrm{m}_{\text {dissolved }} / \mathrm{m}_{\text {dry }}\right) * 100$, where; $\mathrm{m}_{\text {sediment }}$ is the weight of the sediment after removal of the supernatant $(\mathrm{g}), \mathrm{m}_{\mathrm{dry}}$ is the dry weight of the original solid sample $(\mathrm{g})$ and $\mathrm{m}_{\text {dissolved }}$ is the dry weight of the dissolved solids in the supernatant (g). 


\section{Sensory analysis}

Extruded snacks were evaluated according to their preferences for appearance, color, hardness, crispiness, porosity, and overall preference by nine panelists (master students of Department Food Engineering, Middle East Technical University), on a 9 point hedonic scale (1: Dislike extremely to 9: Like extremely). Definitions of the attributes were presented, and the proposed score sheet was explained before the panel. Panelists rinsed their mouths with water between tasting the samples (Caltinoglu, 2014; Caltinoglu et al. 2014).

\section{Statistical analysis}

All the results were analyzed by one-way analysis of variance (ANOVA) for a significant difference $(P \leq 0.05)$. When there was a significant difference, Duncan's Multiple Range Test was applied to determine means which significantly differ from others $(P \leq 0.05)$. The number of replicates for the analysis was given separately under each table.

\section{RESULTS AND DISCUSSION \\ Effect of Extrusion on in vitro Bioaccessibility}

The amount of zeaxanthin and $\beta$-cryptoxanthin decreased after the extrusion process for higher and lower temperature treated samples compared with the feed (Table 2a and b). In vitro bioaccessibility (\%) of zeaxanthin was higher for extruded samples than feed samples (Table 2a). However, in vitro bioaccessibility (\%) values for the feed and extrudates were not different for $\beta$ cryptoxanthin (Table $2 \mathrm{~b}$ ). Thus, even though the extrusion process caused a reduction in the carotenoid contents, the process increased the in vitro bioaccessibility of zeaxanthin (Yeğin, 2104). The cell walls of the red pepper can be mechanically disrupted during extrusion, and the cell compounds can be released into the starchy matrix. Deterioration of the cell wall can improve the release of compounds in the digestive tract. However, at the same time, this can expose the labile compounds such as $\beta$-cryptoxanthin and zeaxanthin molecules to high temperature and shear during extrusion that result in their loss to some extent. In vitro bioaccessibility (\%) of zeaxanthin was higher than $\beta$-cryptoxanthin (Table 2a and b). O'Sullivan et al. (2010) found similar results that bioaccessibilities of red bell pepper carotenoids were $87.6 \%, 54.3 \%, 33.1 \%$, and $6.2 \%$ for zeaxanthin, lutein, $\beta$-cryptoxanthin, and $\beta$-carotene, respectively.

\section{Effect of Extrusion on Total Phenolic} Content and Antioxidant Activity

Total phenolic content was reduced after the extrusion process (Table 3), and raising the temperature from $130^{\circ} \mathrm{C}$ to $160^{\circ} \mathrm{C}$ caused a further reduction. Phenolics are heat-labile compounds; therefore, their structure can be destroyed or altered by heating over $80^{\circ} \mathrm{C}$ (Zielinski et al. 2001). Extrusion cooking could cause a reduction in the chemical reactivity of phenolic compounds or a decrease in their extractability due to a certain degree of polymerization. Antioxidant activity increased with adding red pepper pulp into corn grit (Table 3). The high temperature of extrusion caused a reduction in the antioxidant activity, although increasing the temperature further caused an increase in extrudates' antioxidant activity. The Maillard browning products produced during extrusion cooking could be the reason for the observed increase in antioxidant activity after increasing temperature. During extrusion, high barrel temperatures and low moisture promote the Maillard reaction. It is known that thermal processing produces antioxidants that contribute to antioxidant activity (Tonyalı et al., 2016).

\section{Effect of Red Pepper Pulp Addition on Quality Parameters of Extrudates}

A porous, sponge-like structure was obtained within the extrudates due to the air cells generated during the process. No statistically significant difference was observed for sectional expansion index values between the extrudates with and without red pepper pulp (Table 4a). There is a slight statistically significant increase $(p \leq 0.05)$ in bulk density and a decrease $(\mathrm{p} \leq 0.05)$ in porosity with the addition of red pepper pulp (Table 4a). Similar results were obtained by other researchers, and this was attributed to fiber particles (Moraru and Kokini, 2003). It is known that starch is the main component in expansion phenomena, and 
other ingredients such as protein, sugars, fats, and fiber act as diluents. Fiber particles tended to rupture the cell walls before the gas bubbles had expanded to their full potential. No statistically significant difference was observed in hardness values with the addition of red pepper pulp (Table $4 \mathrm{~b})$ due to the fact that the fiber contribution of the pulps in the studied range was low. Red pepper pulp addition had no statistically significant effect on WAI or WSI (Table 4c), which may be attributed to the fact that the concentration of the fiber was not enough to make changes in the concentration of the starch or dilute starch. WAI can be used as an index of gelatinization, which measures the volume occupied by the granule or starch polymer after swelling, whereas WSI measures the amount of free polysaccharide or polysaccharide released from the granule on the addition of excess water. Statistically significant changes in the color of the extrudates $(P \leq 0.05)$ were observed with the addition of red pepper pulp (data not shown): An increase in redness due to capsanthin and capsorubin and an increase in yellowness due to $\beta$-carotene, violaxanthin, cryptoxanthin, zeaxanthin, antheraxanthin, and $\beta$-cryptoxanthin in the red pepper pulp (Minguez-Mosquera et al. 1993). On the other hand, when the preferences of the panelists were considered, no significant difference was observed (Table 5) for appearance, color, taste, hardness, crispiness, porosity, and general preferences for the extrudates with and without red pepper pulp. Thus, red pepper pulp can be successfully added as a functional ingredient to the extruded products without affecting the acceptability of the products.

Table 2a. Zeaxanthin content of feed and extrudates before and after in vitro digestion.

\begin{tabular}{lcccc}
\hline \multicolumn{4}{c}{ Zeaxanthin $(\mu \mathrm{g} / \mathrm{g}$ dry sample) } \\
\hline Sample & $\begin{array}{c}\text { Before } \\
\text { digestion }\end{array}$ & $\begin{array}{c}\text { Non-dialysable } \\
\text { fraction in the small } \\
\text { intestine }\end{array}$ & $\begin{array}{c}\text { Dialysate } \\
\text { fraction in the } \\
\text { small intestine }\end{array}$ & $\begin{array}{c}\text { Bioaccessibility (\%) } \\
\text { after in vitro digestion }\end{array}$ \\
\hline Feed & $2.97 \pm 0.05^{\mathrm{a}}$ & $1.95 \pm 0.24^{\mathrm{a}}$ & $\mathrm{ND}$ & $65.69 \pm 7.78$ \\
Extrudate $130^{\circ} \mathrm{C}$ & $1.49 \pm 0.14^{\mathrm{b}}$ & $1.21 \pm 0.04^{\mathrm{b}}$ & ND & $81.73 \pm 5.36$ \\
Extrudate $160^{\circ} \mathrm{C}$ & $1.78 \pm 0.21^{\mathrm{c}}$ & $1.48 \pm 0.02^{\mathrm{c}}$ & ND & $84.07 \pm 10.90$ \\
\hline
\end{tabular}

Results are means \pm SD. Two parallels and two replicates were conducted. Different letters indicate significant differences at the 0.05 level $(p<0.05)$. ND, non-detectable.

Table 2b. $\beta$-cryptoxanthin content of feed and extrudates before and after in vitro digestion

\begin{tabular}{lcccc}
\hline \multicolumn{4}{c}{$\beta$-cryptoxanthin $(\mu \mathrm{g} / \mathrm{g}$ dry sample) } \\
\hline Sample & $\begin{array}{c}\text { Before } \\
\text { digestion }\end{array}$ & $\begin{array}{c}\text { Non-dialysable } \\
\text { fraction in the small } \\
\text { intestine }\end{array}$ & $\begin{array}{c}\text { Dialysate fraction } \\
\text { in the small } \\
\text { intestine }\end{array}$ & $\begin{array}{c}\text { Bioaccessibility (\%) } \\
\text { after in vitro digestion }\end{array}$ \\
\hline Feed & $0.97 \pm 0.04^{\mathrm{a}}$ & $0.44 \pm 0.03^{\mathrm{a}}$ & $\mathrm{ND}$ & $45.75 \pm 3.24$ \\
Extrudate $130^{\circ} \mathrm{C}$ & $0.80 \pm 0.01^{\mathrm{b}}$ & $0.35 \pm 0.01^{\mathrm{b}}$ & $\mathrm{ND}$ & $43.52 \pm 1.75$ \\
Extrudate $160^{\circ} \mathrm{C}$ & $0.69 \pm 0.08^{\mathrm{c}}$ & $0.38 \pm 0.02^{\mathrm{b}}$ & $\mathrm{ND}$ & $56.17 \pm 7.71$ \\
\hline
\end{tabular}

Results are means \pm SD. Two parallels and two replicates were conducted. Different letters indicate significant differences at the 0.05 level $(\mathrm{p}<0.05)$. ND, non-detectable.

Table 3. Total phenolic content and antioxidant activity results of corn grit, feed and extrudate samples.

\begin{tabular}{lcc}
\hline Sample & $\begin{array}{c}\text { Total phenolic content } \\
(\mathrm{mg} \mathrm{GAE} / g \text { dry sample) }\end{array}$ & $\begin{array}{c}\text { Antioxidant activity } \\
(\mu \mathrm{mol} \mathrm{TE} / \mathrm{g} \text { dry sample) }\end{array}$ \\
\hline Corn Grits & $1.59 \pm 0.03^{\mathrm{a}}$ & $0.52 \pm 0.003^{\mathrm{a}}$ \\
Feed & $1.51 \pm 0.08^{\mathrm{b}}$ & $0.83 \pm 0.002^{\mathrm{b}}$ \\
Extrudate $130^{\circ} \mathrm{C}$ & $0.88 \pm 0.00^{\mathrm{c}}$ & $0.59 \pm 0.002^{\mathrm{d}}$ \\
Extrudate $160^{\circ} \mathrm{C}$ & $0.79 \pm 0.01^{\mathrm{d}}$ & $0.64 \pm 0.009^{\mathrm{c}}$ \\
\hline
\end{tabular}

Results are means \pm SD ( $=3$ ); values of the same column followed by the different letters indicate significant differences $(p<0.05)$. 
Table 4. Physical properties of the extrudates, with and without red pepper pulp ( $\% 25$ feed moisture), extruded at $145^{\circ} \mathrm{C}$ last zone temperature and $175 \mathrm{rpm}$ with a feeding rate of $36 \mathrm{~g} / \mathrm{min}$.

a. SEI, Bulk density and Porosity

\begin{tabular}{lcc}
\hline & Corn Grit & Red Pepper Pulp Added \\
\hline SEI & $5.84 \pm 0.74^{\mathrm{a}}$ & $5.80 \pm 0.72^{\mathrm{a}}$ \\
Bulk Density & $0.230 \pm 0.001^{\mathrm{a}}$ & $0.296 \pm 0.007^{\mathrm{b}}$ \\
Porosity & $0.85 \pm 0.01^{\mathrm{a}}$ & $0.80 \pm 0.01^{\mathrm{b}}$ \\
\hline
\end{tabular}

Bulk Density results are means \pm SD $(n=5)$; SEI results are means \pm SD $(n=30)$; Porosity results are means \pm $\mathrm{SD}(\mathrm{n}=5)$; values of the same row, followed by the same letter (a) are not statistically different $(P \leq 0.05)$.

b. Hardness values of the extrudates with and without red pepper pulp ( $\% 25$ feed moisture), extruded at $145^{\circ} \mathrm{C}$ last zone temperature and $175 \mathrm{rpm}$ with a feeding rate of $36 \mathrm{~g} / \mathrm{min}$.

\begin{tabular}{lc}
\hline & Hardness $(\mathrm{N})$ \\
\hline Corn Grit & $9.83 \pm 1.19^{\mathrm{a}}$ \\
Red Pepper Pulp Added & $10.77 \pm 1.35^{\mathrm{a}}$ \\
\hline
\end{tabular}

Results are means \pm SD ( $n=25)$; values of the same colon, followed by the same letter (a) are not statistically different $(P \leq 0.05)$.

c. WAI and WSI values.

\begin{tabular}{lll}
\hline & Corn Grit & Red Pepper Pulp \\
\hline WAI $\left(\right.$ g. $\left.\mathrm{g}^{-1}\right)$ & $4.79 \pm 0.13^{\mathrm{a}}$ & $4.76 \pm 0.33^{\mathrm{a}}$ \\
WSI $(\%)$ & $9.58 \pm 0.94^{\mathrm{a}}$ & $10.88 \pm 2.39^{\mathrm{a}}$ \\
\hline
\end{tabular}

WAI and WSI results are means \pm SD $(\mathrm{n}=6)$; values of the same row, followed by the same letter (a) are not statistically different $(P \leq 0.05)$.

Table 5. Sensory evaluation scores of extrudates with and without red pepper pulp $(\% 25$ feed moisture), extruded at $145^{\circ} \mathrm{C}$ last zone temperature and $175 \mathrm{rpm}$ with a feeding rate of $36 \mathrm{~g} / \mathrm{min}$.

\begin{tabular}{lcc}
\hline & Corn Grit & Red Pepper Pulp Added \\
\hline Appearance & $7.22 \pm 1.09^{\mathrm{a}}$ & $7.00 \pm 1.32^{\mathrm{a}}$ \\
Color & $7.22 \pm 1.10^{\mathrm{a}}$ & $7.67 \pm 1.50^{\mathrm{a}}$ \\
Taste & $6.67 \pm 1.80^{\mathrm{a}}$ & $6.67 \pm 1.58^{\mathrm{a}}$ \\
Hardness & $6.78 \pm 2.28^{\mathrm{a}}$ & $7.00 \pm 1.58^{\mathrm{a}}$ \\
Crispiness & $7.33 \pm 1.58^{\mathrm{a}}$ & $7.00 \pm 0.87^{\mathrm{a}}$ \\
Porosity & $7.11 \pm 1.05^{\mathrm{a}}$ & $7.00 \pm 0.50^{\mathrm{a}}$ \\
General Preferences & $6.78 \pm 1.72^{\mathrm{a}}$ & $7.00 \pm 1.00^{\mathrm{a}}$ \\
\hline
\end{tabular}

Results are means \pm SD ( $\mathrm{n}=9$ ); values of the same row, followed by the same letter (a) are not statistically different $(P \leq 0.05)$.

\section{CONCLUSIONS}

In vitro bioaccessibility of zeaxanthin was increased by the extrusion process, while the process did not significantly affect in vitro bioaccessibility of $\beta$-cryptoxanthin. Total phenolic content, antioxidant activities, $\beta$ cryptoxanthin, and zeaxanthin content decreased by the extrusion process. Physical quality parameters such as hardness, expansion, water absorption, and water solubility index values were not affected by red pepper pulp addition. Porosity decreased, and hence the bulk density increased slightly. Due to the red pepper's carotenoid content, the color of the extrudates changed after the pulp addition. Sensory analysis showed that panelists' preference scores were as high as the control for the red pepper pulp added samples. The information gained in this research put the significance of structural damage of the food matrix during processing on the in vitro bioaccessibility. In addition, it was shown that red pepper pulp could be added successfully as a functional ingredient to the corn grit extrudates to 
develop new products without any change in consumer preferences.

\section{ACKNOWLEDGMENTS}

This research is a part of the project (TUBITAK1100792) funded by The Scientific and Technological Council of Turkey. The authors would also like to thank Dr. Zinet Aytanga Okmen for her laboratory support during HPLC analyses.

\section{CONFLICT OF INTEREST}

The authors declare no conflict of interest.

\section{AUTHOR CONTRIBUTION}

Ozge Yoldas: Methodology, Writing-original draft; Cagla Caltinoglu-Toraman: Methodology, Writing-original draft; Ilkay Sensoy: Conceptualization, Funding acquisition, Supervision, Writing-original draft, Writingreview \& editing; Sibel Karakaya: MethodologyIn vitro model

\section{REFERENCES}

Abdel-Aal, E.-S., Akhtar, H., Zaheer, K. and Ali, R. (2013). Dietary sources of lutein and zeaxanthin carotenoids and their role in eye health. Nutrients 5, 1169-1185.

Anton, A. A., Fulcher, R. G. and Arntfield, S. D. (2009). Physical and nutritional impact of fortification of corn starch-based extruded snacks with common bean (Phaseolus vulgaris L.) flour: effects of bean addition and extrusion cooking. Food Chem, 113, 989-996.

Çaltinoğlu, Ç. (2014). Effect of tomato, red pepper and carrot pulp addition on the quality of extrudates. Master of Science Thesis, Middle East Technical University, Ankara, TURKEY.

Caltinoglu, C., Tonyalı, B. and Sensoy, I. (2014). Effects of tomato pulp addition on the extrudate quality parameters and effects of extrusion on the functional parameters of the extrudates. Int J Food Sci Techn, 49(2), 587-594.

Carrilo C., Buve, C., Panozzo A., Grauwet, T. and Hendrickx, M. (2017). Role of structural barriers in the in vitro bioaccessibility of anthocyanins in comparison with carotenoids. Food Chem, 227, 271-279.

Cemeroglu, B. (2010). Gida Analizleri. Ankara: Gıda Teknolojisi Derneği Yayınları.

Dehghan-Shoar, Z., Mandimika, T., Hardacre, A. K., Reynolds, G. W. and Brennan, C. S. (2011). Lycopene bioaccessibility and starch digestibility for extruded snacks enriched with tomato derivatives. J Agr Food Chem, 59, 12047-12053.

Guven, O., Sensoy, I., Senyuva, H., Karakaya, S. (2018). Food processing and digestion: The effect of extrusion process on bioactive compounds in extrudates with artichoke leaf powder and resulting in vitro cynarin and cynaroside bioaccessibility. LWT - Food Sci Techn, 90, 232-237. https://doi.org/10.1016/j.lwt.2017.12.042

Karakaya, S., Simsek, S., Eker, A.T., PinedaVadillo, C., Dupont, D., Perez, B., Viadel, B., Sanz-Buenhombre, M., Rodriguez, A.G., Kertesz, Z., Hegyi, A., Bordoni, A., El, S.N. (2016). Stability and bioaccessibility of anthocyanins in bakery products enriched with anthocyanins. Food and Function, 7(8), 3488-3496

Kopf-Bolanz, K. A, Schwander, F., Gijs, M., Vergeres, G., Portmann, R. and Egger, L. (2012). Validation of an in vitro digestive system for studying macronutrient decomposition in humans. J Nutr, 142, 245-250.

Krinsky, N. I., Landrum, J. T. and Bone, R. A. (2003). Biologic mechanisms of the protective role of lutein and zeaxanthin in the eye. Ann Review Nutr, 23, 171-201.

Moraru, C. I., and Kokini, J. L., 2003. Nucleation and Expansion During Extrusion and Microwave Heating of Cereal Foods. Compr Rev Food Sci Food Safety, 2(4), 147-165.

Martos, G., Conteras, P., Molina, E. and LopezFandino R. (2010). Egg white ovalbumin digestion mimicking physiological conditions. $J$ Agr Food Chem, 58, 5640-5648.

Minguez-Mosquera, M. I. and Hornero-Mendez, D. (1993). Separation and quantification of the carotenoid pigments in red peppers (Capsicum annum L.), paprika, and oleoresin by reversedphase HPLC. J Agr Food Chem, 41, 1616-1620. 
Mozaffarieh, M., Sacu, S. and Wedrich, A. (2003). The role of carotenoids, lutein and zeaxanthin, in protecting against age-related macular degeneration: A review based on controversial evidence. Nutr J, 11, 20-28.

O'Connell, O. F., Ryan, L. and O'Brien, N. M. (2007). Xanthophyll carotenoids are more bioaccessible from fruits than dark green vegetables. Nutr J, 27, 258-264.

O'Sullivan, L., Jiwan, M. A., Daly, T., O'Brien, N. M. and Aherne, S. A. (2010). Bioaccessibility, uptake, and transport of carotenoids from peppers (Capsicum spp.) using the coupled in vitro digestion and human intestinal Caco-2 cell model. J Agr Food Chem, 58, 5374-5379.

Pai, D. A., Blake, O. A., Hamaker, B. R. and Campanella, O. H. (2009). Importance of Extensional Rheological Properties on FiberEnriched Corn Extrudates. J Cereal Sci, 50(2), 227234.

Pineda-Vadillo, C. , Nau, F., Guerin-Dubiard, C ., Jardin, J., Lechevalier, V., Sanz-Buenhombre, M., Guadarrama, A., Toth, T., Csavajda, E., Hingyi, H., Karakaya, S., Sibakov, J., Capozzi, F., Bordoni, A., Dupont, D. (2017). The food matrix affects the anthocyanin profile of fortified egg and dairy matrices during processing and in vitro digestion. Food Chem, 214, 486-496.
Sahin, S. and Sumnu, S. G. (2006). Physical Properties of Foods, Springer: New York.

Tonyali, B., Sensoy, I., Karakaya, S. (2020). Effects of processing on onion skin powder added extrudates. J Food Sci Techn, 57, 3426-3435.

Tonyali, B., Sensoy, I., Karakaya, S. (2016). The effect of extrusion on the functional components and in vitro lycopene bioaccessibility of tomato pulp added corn extrudates. Food Funct.,7, 855860.

Van Buggenhout, S., Alminger, M., Lemmens, L., Colle, I., Knockaert, G. and Moelants, K. (2010). In vitro approaches to estimate the effect of food processing on carotenoid bioavailability need thorough understanding of process induced microstructural changes. Trends Food Sci Tech 21(12), 607-618.

Yeğin, Ö. (2014). Effect of extrusion on functional components and in vitro bioaccessibilty of $\beta$-cryptoxanthin and zeaxanthin. Master of Science Thesis, Middle East Technical University, Ankara, TURKEY.

Zielinski, H., Kozlowska, H. and Lewczuk, B. (2001). Bioactive compounds in the cereal grains before and after hydrothermal processing. Innovative Food Sci and Emerg Techn, 2, 159-169. 